\title{
THE GEOLOGY, MINERALOGY AND NEAR SURFACE CHARACTERISTICS OF THE ASHMORE AND SEPPELT KIMBERLITE CLUSTERS, NORTH KIMBERLEY PROVINCE, AUSTRALIA
}

\author{
Tom Reddicliffe*, Janusz Jakimowicz, Adrian Hell and Justin Robins \\ Striker Resources NL, Australia
}

The Seppelt and Ashmore kimberlite clusters are situated in the north Kimberley region of Western Australia (figure 1). The emplacement of the kimberlites, which all intrude Proterozoic volcanic and sedimentary rocks of the Kimberley basin, is controlled by $30^{\circ}$ trending structures. $\mathrm{Rb} / \mathrm{Sr}$ dating on phlogopite suggest consistent emplacement ages of Neoproterozoic (774 $\pm 279 \mathrm{Ma})$ (Wyatt et al., 1998) for both clusters. These kimberlite clusters occur $20 \mathrm{~km}$ apart and form single to bifurcating pipe-like bodies with an associated outer, often collapsed and dipping, contact breccia (figure 2).

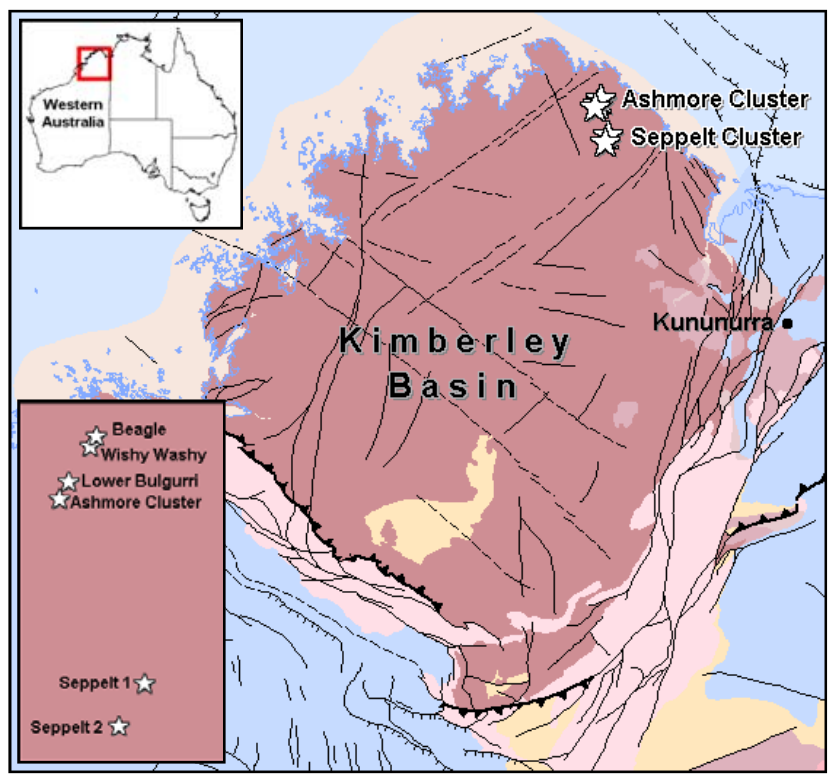

Figure 1: Location and distribution of Ashmore and Seppelt kimberlites and associated kimberlite dyke and breccia pipes.

All of the kimberlite pipes comprise altered hypabyssal macrocrystic kimberlite (figure 3), phlogopitic kimberlite and lithic hypabyssal kimberlite breccia (figure 4). No diatreme facies kimberlite has been observed, indicating these pipes have eroded to a level within the root zone (Mitchell, 1995) and/or represents an immature and underdeveloped kimberlite pipe system. The textural phases in all pipes exhibit gradational contacts and are irregularly distributed throughout the near surface bodies. The only exception being the kimberlite breccia, which is a peripheral zone separating the macrocrystic kimberlite from the surrounding country rock, and which widens near the intersection of the $30^{\circ}$-emplacement structure.

The Seppelt 1 and possibly Seppelt 2 kimberlites, form bifurcating pipes, comprising two distinct lobes covering a total area of 1.0 ha and 0.08 ha respectively. The two lobes of Seppelt 1 are conjoined by a relatively thin often sub-outcropping kimberlite dyke, which is controlled along the main emplacement structure. Sandstone breccias and a thin kimberlite dyke occur in close proximity to the Seppelt 1 kimberlite, along and associated with parallel trending $30^{\circ}$ structures. The textural phases are similar between both north and south lobes and within the conjoining and associated kimberlite dyke complexes.

The Ashmore kimberlite cluster is an en-echelon array of three individual pipes varying in size from 0.3 ha to 0.5 ha. In near proximity to these pipes are multiple thin and extensive dyke systems including the Lower Bulgurri, Wishy-Washy and Beagle kimberlite (Hell, 2002a) (figure 1).

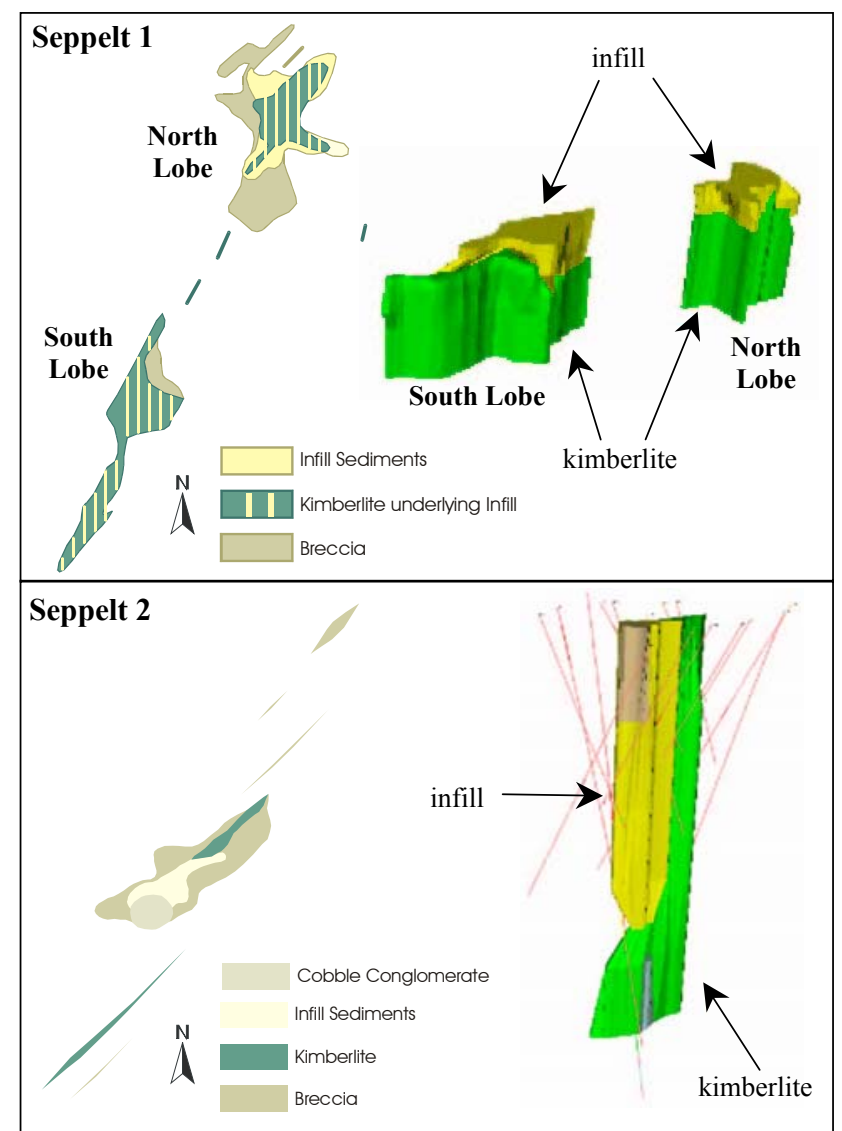

Figure 2: Interpreted shape and plan view of the Seppelt 1 and 2 kimberlite pipes. 


\section{Mineralogy}

The macrocrystic kimberlite (figure 3) in both the Ashmore and Seppelt clusters consists a primary mineralogy comprising pseudomorphed olivine macrocrysts (20-35 vol.\%) and phenocrysts (10-20 vol.\%) now replaced by serpentine, chlorite, carbonate and silica. Altered phlogopite (20-65 vol.\%) laths and plates occur as groundmass and phenocryst phases with less common poikilitic phlogopite enclosing chromite. Calcite commonly replaces phlogopite. Opaque minerals (5-10 vol.\%) include chromite, spinel, magnetite and ilmenite. Uncommon apatite (5 vol.\%) occurs as a groundmass phase and as inclusions within many silicate and opaque minerals. In addition to the above mentioned phases, groundmass rutile ( 5 vol.\%) occurs within the Ashmore 2 kimberlite. Other additional phases within Seppelt 1 kimberlite comprise perovskite (5 vol.\%), former monticellite (10 vol \%), zircon, and rare diopside $(<1$ vol.\%). Xenoliths from all kimberlites may comprise quartzite, siltstone, mudstone and basalt, with rare mantle xenoliths being noted (Wyatt et. al., 1998).

The whole rock geochemistry (Table 1) of the Ashmore 1 kimberlite (Chinyepi, 2001) show similarities to both kimberlite (Group 1) and orangeite (Group 2) (Mitchell, 1995) (figures 5, $6 \& 8$ ). Mineral chemistry of phlogopite and spinel (Rockett, 1997 \& Chinyepi, 2001) from Ashmore 1 show strong affinities to orangeite (Group 2 kimberlite), which currently remains problematic, and would imply the first of this group outside of Africa. The mineral chemistry of spinels from Ashmore 2, however, conforms to group 1 kimberlite (figure 9). Seppelt 1 and 2 , display an average whole rock geochemistry characteristic of both kimberlite and orangeite groups (figures 5, 6, $7 \& 8$ ), however based on petrographical observations and spinel mineral chemistry (figure 9) Seppelt 1 comprises a characteristic monticellitephlogopite kimberlite (Mitchell, 1995) of group 1 variety. These are consistent with previous results by Wyatt et. el., (1998).

All these kimberlites are overlain and 'corked' by a restricted and localised infill-sequence circumscribed by the Pentecost Sandstone and Warton Sandstone wall rock (figure 10). The infill-sequence overlying the Seppelt pipes (Hell, 2002b) comprises a basal kaolinitemicaceous-sulphide rich horizon, containing abundant non-definitive organic matter (Hell, 2002c). Conformably and gradationally overlying the basal claystone is an upper mottled and 'spotty' appearing kaolinitemicaceous-talc claystone often highly ferruginised. These claystone sediments are overlain by a laminated claystone and pebble-boulder conglomerate, often containing large rafts of country wall rock. Within the Ashmore pipes the basal claystone is absent, and in addition, overlying and capping the conglomerate is a massive friable sandstone.

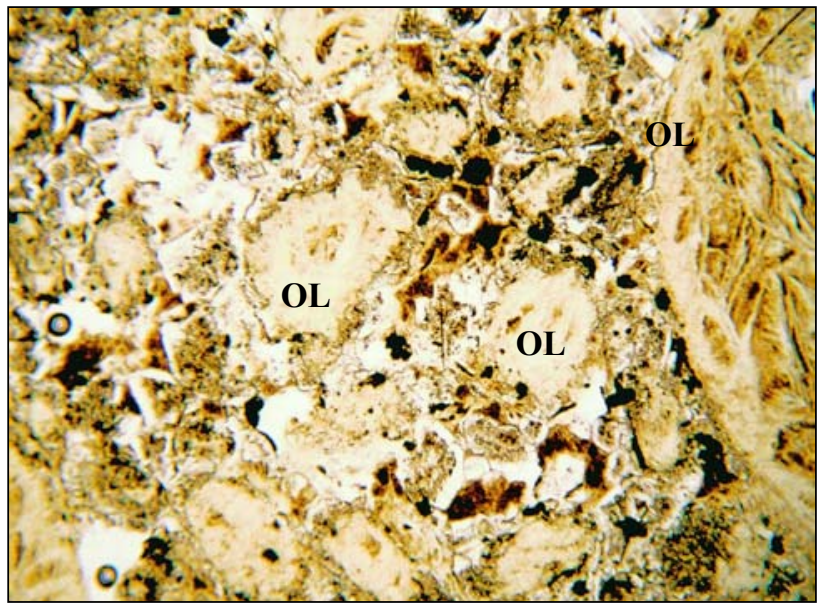

Figure 3: Photomicrograph of characteristic macrocrystic hypabyssal kimberlite texture $(\mathrm{x} 40 \mathrm{mag})(\mathrm{ppl})$. Olivine $(\mathrm{OL})$ altered to dominantly serpentine set within a calcite and serpentine groundmass.

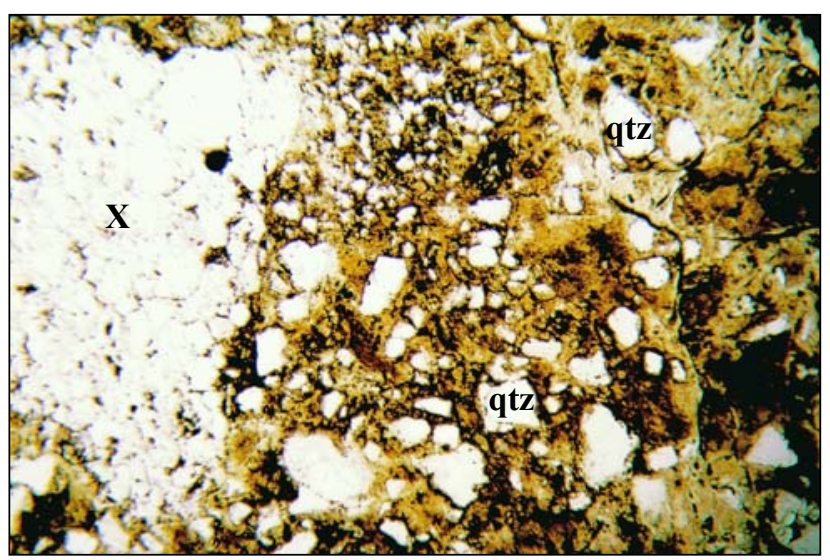

Figure 4: Photomicrograph of characteristic hypabyssal kimberlite breccia (x40mag)(ppl), comprising quartzite xenoliths (X) often fragmenting into quartz xenocrysts (qtz).

The infill sediments especially the claystone units contain silicified kimberlite clasts and a higher percentage of diamonds and indicator minerals relative to the underlying kimberlite. The capping sandstone overlying Ashmore is the only unit barren of these diamond and indicator minerals. The composition of the infill sediments suggests a significant contribution from the erosion of local kimberlite within an interface of possible shallow marine and terrestrial lake or swamp conditions. The conglomerate infill-sequence overlying Seppelt 2 comprises two populations of diamonds, one consistent with those identified from near surface kimberlite and a second, unresolved population, possibly associated with another parental textural phase or another separate and independent kimberlite body near or surrounding area. 


\begin{tabular}{|c|c|c|c|c|c|c|c|c|c|c|c|}
\hline Major (wt.\%) & $\mathrm{SiO}_{2}$ & $\mathrm{TiO}_{2}$ & $\mathbf{A l}_{2} \mathbf{O}_{3}$ & $\mathrm{Fe}_{2} \mathrm{O}_{3}$ & MnO & MgO & $\mathrm{CaO}$ & $\mathrm{Na}_{2} \mathrm{O}$ & $\mathbf{K}_{2} \mathrm{O}$ & $\mathrm{P}_{2} \mathrm{O}_{5}$ & LOI \\
\hline Ashmore 1 & 37.5 & 1 & 3 & 9.4 & 0.17 & 32.3 & 2.4 & 0.1 & 5.2 & 0.3 & 11.3 \\
\hline Ashmore 2 & 34.7 & 0.9 & 2.7 & 9.1 & 0.17 & 31.8 & 4.9 & 0.03 & 1.1 & 0.4 & 14.2 \\
\hline Seppelt 1 & 40.5 & 1.1 & 2.7 & 9.1 & 0.1 & 30.8 & 9.2 & 0.2 & 1 & 0.2 & 10.8 \\
\hline Seppelt 2\# & 33.8 & 19 & 28.6 & 2.2 & 0 & 0.4 & 0.2 & 0 & 0.1 & 1.1 & 12.5 \\
\hline Trace Elements* & Sc & $\mathbf{V}$ & $\mathrm{Cr}$ & Co & $\mathrm{Ni}$ & $\mathbf{C u}$ & $\mathrm{Zn}$ & $\mathbf{G a}$ & $\mathbf{G e}$ & As & $\mathbf{R b}$ \\
\hline Ashmore 1 & 14.6 & 50.9 & 1694.3 & 93.2 & 1331.43 & 63.3 & 74.3 & 4.5 & 1 & $<5$ & 100 \\
\hline Ashmore 2 & 15 & 65.4 & 1625 & 73.9 & 1163.1 & 22 & 74.3 & 3.6 & $<1$ & $<5$ & 61.4 \\
\hline Seppelt 1 & 15 & 64.35 & 1535.8 & 75.5 & 1385.6 & 70.3 & 72.8 & 4.3 & 1.35 & 5.1 & 71.4 \\
\hline Seppelt 2\# & 63 & 388.1 & 9425 & 5.5 & 168.6 & 21.5 & 291 & 38.6 & 0 & 4.8 & 1.5 \\
\hline Trace Elements* & $\mathrm{Sr}$ & $\mathbf{Y}$ & $\mathbf{Z r}$ & $\mathrm{Nb}$ & Mo & Ag & Sn & Sb & Cs & Ba & \\
\hline Ashmore 1 & 283 & 9.5 & 103.1 & 118.1 & $<2$ & $<0.5$ & 1 & $<0.5$ & 1.4 & 921.4 & \\
\hline Ashmore 2 & 353.9 & 7.6 & 76.3 & 104.1 & $<2$ & 2 & $<0.5$ & 1.6 & 0.6 & 973.6 & \\
\hline Seppelt 1 & 341.6 & 6.7 & 105.8 & 70.2 & $<2$ & $<0.5$ & 1.1 & $<0.5$ & 2.2 & 809.1 & \\
\hline Seppelt 2\# & 927.7 & 245.9 & 1528.1 & 1584.5 & 0 & 0 & 8.4 & 1 & 0 & 2613.1 & \\
\hline $\begin{array}{l}\text { Rare Earth } \\
\text { Elements* }\end{array}$ & La & $\mathrm{Ce}$ & Pr & Nd & Sm & Eu & Gd & $\mathbf{T b}$ & Dy & Ho & Er \\
\hline Ashmore 1 & 84.2 & 163.1 & 17.8 & 60 & 8.2 & 2.03 & 6 & 0.5 & 2.1 & 0.4 & 0.9 \\
\hline Ashmore 2 & 90.8 & 162.2 & 17.1 & 56.2 & 22.2 & 1.8 & 5.6 & 0.5 & 1.8 & 0.3 & 0.6 \\
\hline Seppelt 1 & 41.3 & 81.4 & 9.4 & 33.1 & 5.4 & 1.4 & 3.8 & 0.4 & 1.7 & 0.3 & 0.7 \\
\hline Seppelt 2\# & 856.8 & 1224 & 150 & 532.5 & 84.7 & 23.1 & 75.3 & 8.7 & 48.1 & 8.1 & 20.5 \\
\hline $\begin{array}{l}\text { Rare Earth } \\
\text { Elements* }\end{array}$ & $\mathbf{T m}$ & $\mathbf{Y b}$ & Hf & $\mathbf{T a}$ & $\mathbf{W}$ & $\mathbf{T l}$ & $\mathbf{P b}$ & $\mathbf{B i}$ & Th & $\mathbf{U}$ & \\
\hline Ashmore 1 & 0.1 & 0.6 & 2.7 & 9.6 & 0.73 & 0.1 & 5.3 & $<2$ & 16.3 & 2.4 & \\
\hline Ashmore 2 & 0.1 & 0.4 & 2 & 11 & 3.1 & 0.1 & 5.1 & 0.2 & 36.5 & 5.9 & \\
\hline Seppelt 1 & 0.1 & 0.5 & 2.9 & 11.5 & $<0.5$ & $<0.1$ & 5.9 & $<0.2$ & 9.9 & 1.8 & \\
\hline Seppelt 2\# & 2.3 & 12.3 & 42.8 & 100.5 & 18.2 & 0 & 347.9 & 0.4 & 152.5 & 31.6 & \\
\hline
\end{tabular}

Table 1: Average whole rock geochemistry for Seppelt and Ashmore kimberlite clusters. [* $=$ ppm, \# $=$ near surface weathered kimberlite]

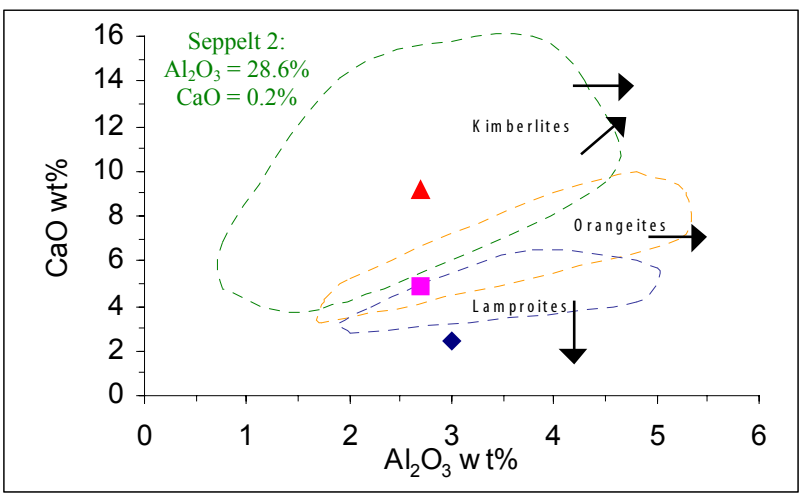

Figure 5: Average whole rock $\mathrm{Al}_{2} \mathrm{O}_{3}$ vs $\mathrm{CaO}$ wt.\% plot for Ashmore and Seppelt kimberlite clusters (after Taylor et. al., 1994).

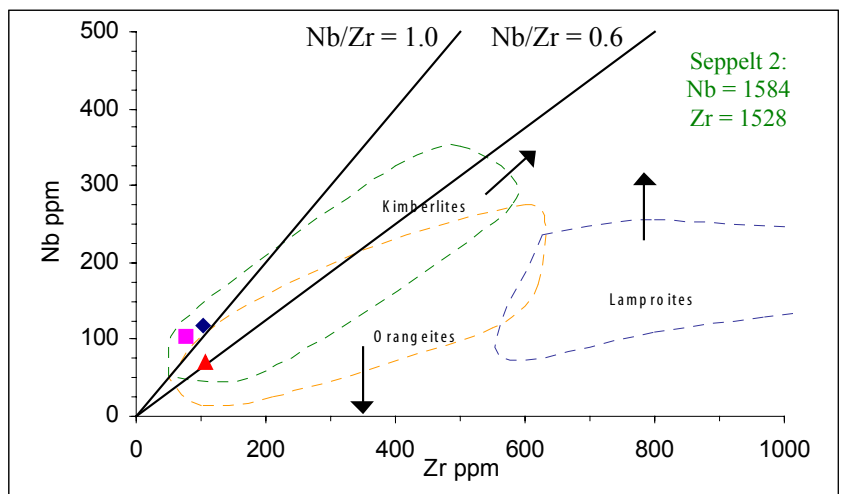

Figure 6: Average whole rock $\mathrm{Zr}$ vs $\mathrm{Nb}$ (ppm) plot for Ashmore and Seppelt kimberlite cluster (after Taylor et. al.,1994)

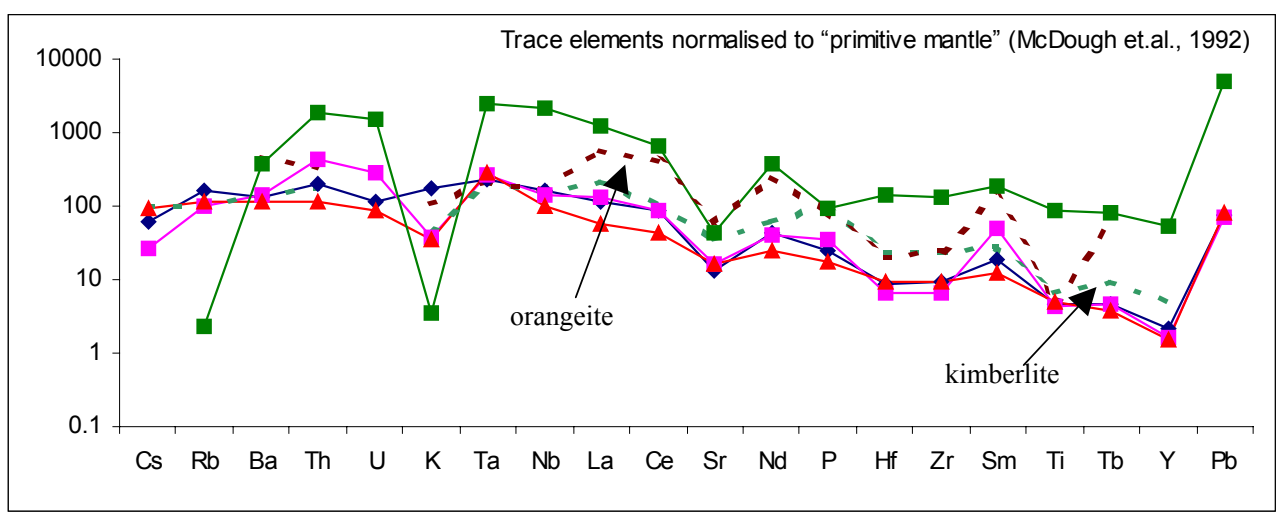

Key for Figures

$6,7,8$ and 9.

Ashmore 1

Ashmore 2

$\triangle$ Seppelt 1

Seppelt 2

Figure 7: Average trace element patterns for the Ashmore and Seppelt kimberlite clusters with comparisons to kimberlite (Group I) (Mitchell, 1995) and orangeites (Group II) (Wedepohl \& Muramati, 1979). 


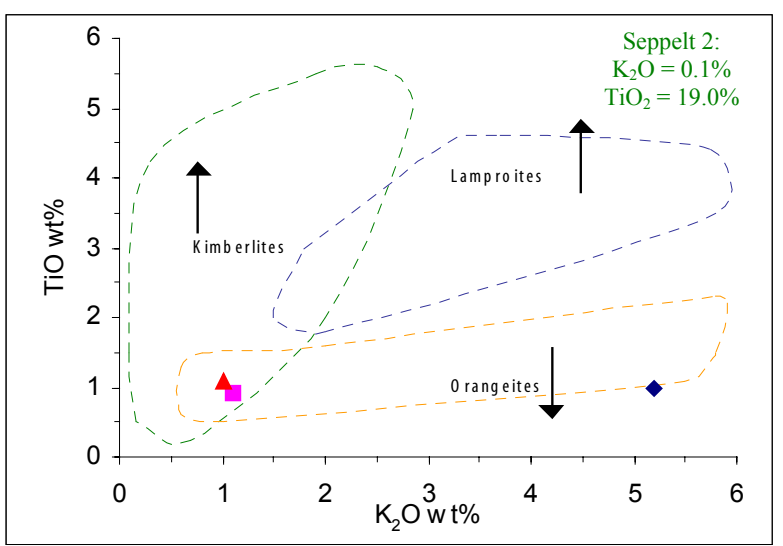

Figure 8: Average whole rock $\mathrm{K}_{2} \mathrm{O}$ vs $\mathrm{Tio}_{2}$ wt. $\%$ plot for the Ashmore and Seppelt kimberlite clusters (Taylor, 1994) .

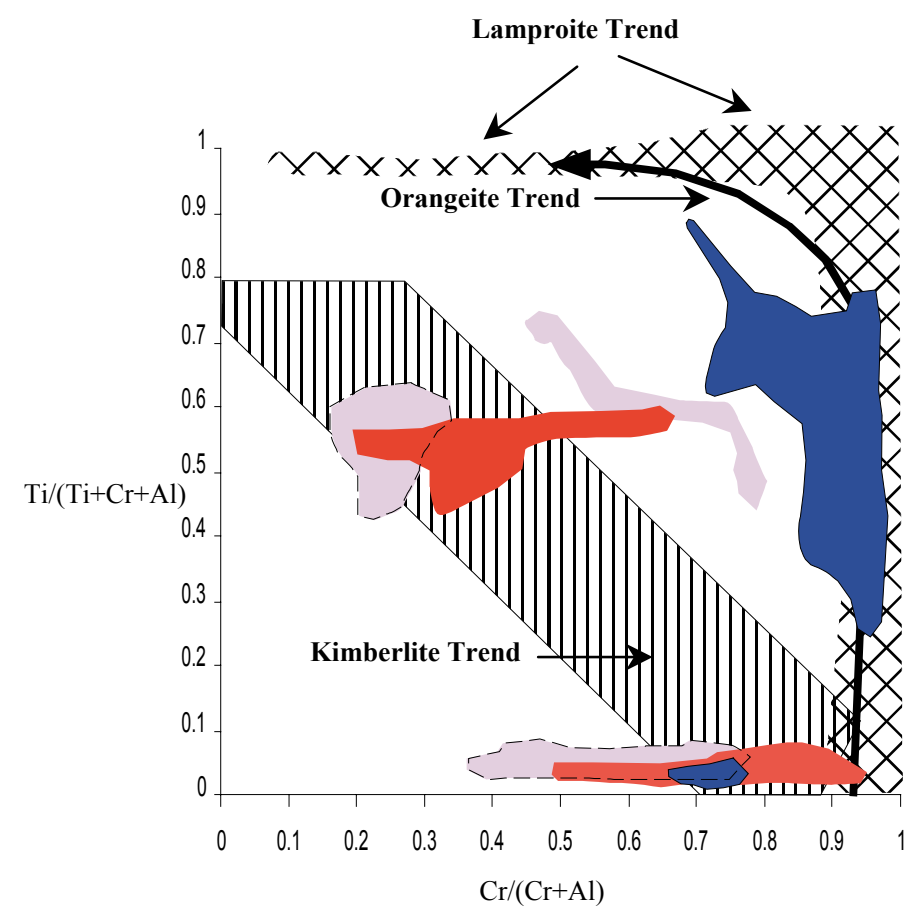

Figure 9: $\mathrm{Ti} /(\mathrm{Ti}+\mathrm{Cr}+\mathrm{Al})$ vs $\mathrm{Cr} /(\mathrm{Cr}+\mathrm{Al})$ trends for kimberlite spinels. Combined core and rim analysis from

Ashmore 1,

Ashmore 2, and

Seppelt 1 kimberlites.

(Amended after Rockett (1997), Mitchell (1995) and Chinyepi (2001).

The thickness of the infill-sequences ranges from 22.0 to $30.0 \mathrm{~m}$, however over an area of the Seppelt 2 kimberlite these sediments appear to reach a thickness of $130.0 \mathrm{~m}$. Superimposed over the infill-sequences and the surrounding country rock is a weathering profile and surficial sands and silts.

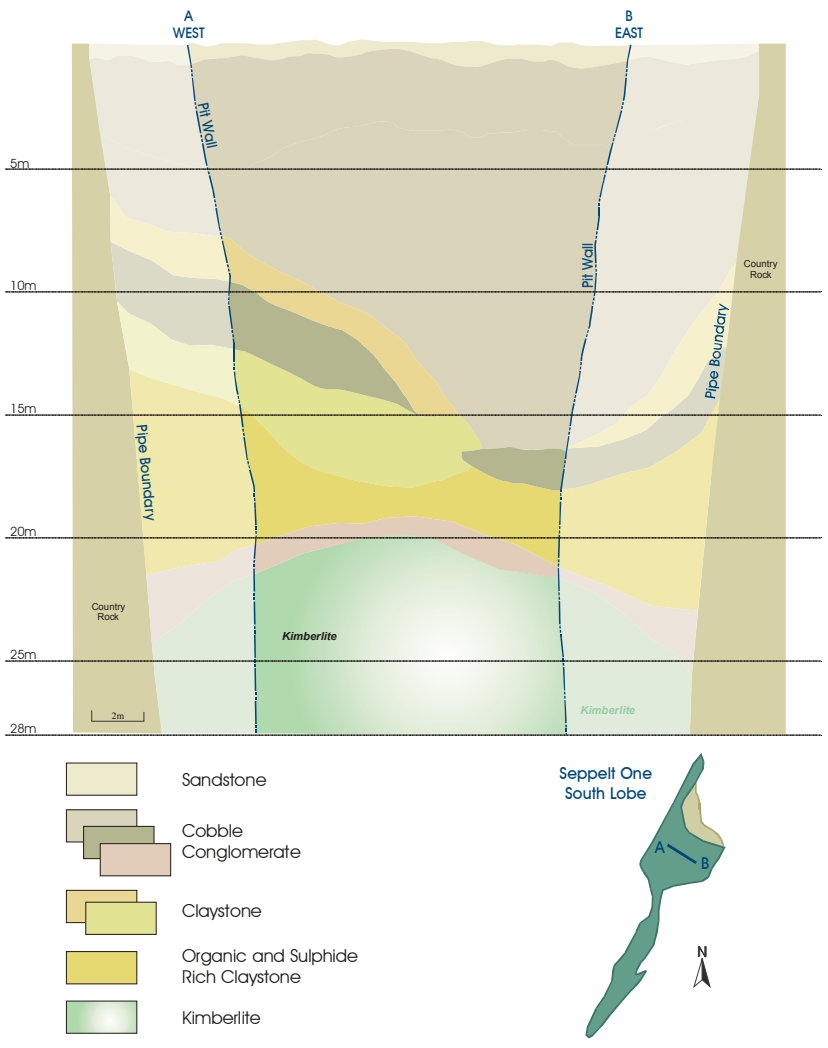

Figure 10: Schematic section of the infill sequence overlying Seppelt 1 kimberlite.

The kimberlites in both clusters display slickenside features near the pipe margins and within the overlying claystone and conglomerate, suggesting the infillsequence has been preserved as a result of post depositional subsidence. Further evidence supporting this process is the presence of thin kimberlite selvages at the pipe margins near the surface. Due to the absence of definitive polymorphs and other microfossils within the infill-sediments an age relationship between emplacement, deposition of sediments, and the subsequent subsidence of the kimberlite is currently difficult to establish.

Ashmore and Seppelt kimberlites both show in-situ weathering down to an average depth of $50 \mathrm{~m}$ that has resulted in the destruction of pyrope garnet, diopside, olivine and phlogopite. Treatment of Ashmore and Seppelt weathered kimberlite material reported diamonds along with abundant chromite, minor pyrope and diopside. Phlogopite and serpentinised olivine were found below the weathered zone. The indicator minerals recovered from both clusters have compositions typical of grains derived from peridotitic rocks in the deeper mantle. Major and trace analyses of various indicator minerals show chemistry consistent with sampling within the diamond stability field. A significant proportion of 
chromite shows titanium enrichment, which can be related to metasomatic processes within the mantle.

\section{References}

Chinyepi, G.G., 2001. Classification of Ashmore 1 pipe, Ashmore 2 pipe, Lower Bulgurri fissure and Seppelt 1 pipe into Group -I and Group-II (orangeites) kimberlites. [Master] Thesis, University of Western Australia, Australia, pgs 67.

Hell, A.J., 2002a. Beagle kimberlite - Bulk sample, Striker Resources Job Report No: 02-136, Perth, Australia.

Hell, A.J., 2002b. Seppelt 1 - bulk sample, Striker Resources Job Report No: 02-075, 02-076, 02-077, 02-078, \& 02079, Perth, Australia.

Hell, A.J., 2002c Polymorph analysis of infill sediments, Striker Resources Job Report No.02-124, Perth, Australia.

Mitchell, R.H., 1995. Kimberlites, orangeites and related rocks, Plenum Press, pgs 409.

Rockett, G.M.I., 1997. Petrology and weathering of the diamondiferous Ashmore No. 1 pipe and Lower Bulgurri fissure in the North Kimberley Province, Western Australia, (Honours) Thesis, University of Western Australia, pgs 126.

Rollison, H.R., 1993. Using geochemical data: evaluation, presentation, interpretation, Prentice Hall, pgs 352.

Taylor, W.R., Tompkins L.A., and Haggerty S.E. 1994. Comparative geochemistry of West African kimberlites: Evidence for a micaceous kimberlite endmember of sublithospheric origin. Geochemica et Cosmochimia Acta 58, pp. 4017-4037.

Wedepohl, K.H., Muramati, Y., 1979. The chemical composition of kimberlites compared with average composition of three basalt magma types. In: FR Boyd and HOA Meyer, (eds). Proceedings of the Second International Kimberlite Conference. Vol.1. Kimberlites, diatremes and diamonds: their geology, petrology and geochemistry. American Geophysical Union, Washington, D.C., pp 300-312.

Wyatt, B.A., Sumpton, J.D.H., Steifenhofer, J., Shee, S.R., Smith, T.W. 1998. Kimberlites in the Forrest River Area, Kimberley Region, Western Australia, Proceedings of the 7th International Kimberlite Conference, Cape Town, South Africa, pp 912-922.

Contact: T.H Reddicliffe, Striker Resources NL, Level 10, 256 Adelaide Terrace, Perth, Western Australia, Australia, 6000, Phone: +61 89221 3355, Fax: +61 892211730

E-mail: tomr@striker.com.au 